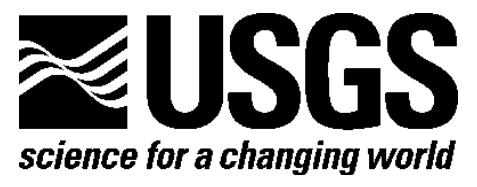

Prepared in cooperation with the National Park Service

\title{
Revised Geologic Cross Sections of Parts of the Colorado, White River, and Death Valley Regional Groundwater Flow Systems, Nevada, Utah, and Arizona
}

By William R. Page, Daniel S. Scheirer, Victoria E. Langenheim, and Mary A. Berger

Open-File Report 2006-1040

Revised June, 2011

U.S. Department of the Interior U.S. Geological Survey 


\section{U.S. Department of the Interior KEN SALAZAR, SECRETARY}

\section{U.S. Geological Survey \\ Marcia K. McNutt, Director}

U.S. Geological Survey, Denver, Colorado, 2011

Revised June, 2011

For product and ordering information: World Wide Web: http://www.usgs.gov/pubprod Telephone: 1-888-ASK-USGS

For more information on the USGS-the Federal source for science about the Earth, its natural and living resources, natural hazards, and the environment: World Wide Web: http://www.usgs.gov Telephone: 1-888-ASK-USGS

Suggested citation: Page, W.R., Scheirer, D.S., Langenheim, V.E., and Berger, M.A., 2011, Revised geologic cross sections of parts of the Colorado, White River, and Death Valley regional groundwater flow systems, Nevada, Utah, and Arizona: U.S. Geological Survey Open-File Report 2006-1040, Denver, CO, 80225.

Any use of trade, product, or firm names is for descriptive purposes only and does not imply endorsement by the U.S. Government. Although this report is in the public domain, permission must be secured from the individual copyright owners to reproduce any copyrighted material contained within this report. 


\section{Contents}

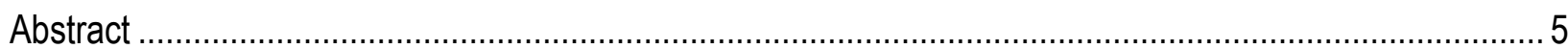

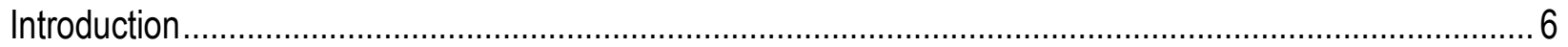

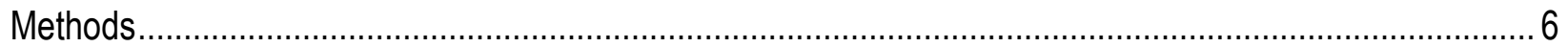

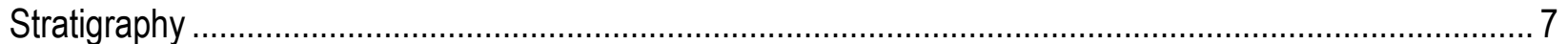

Proterozoic and Paleozoic Rocks .............................................................................................. 7

Late Proterozoic-Paleozoic Facies Belts ................................................................................. 9

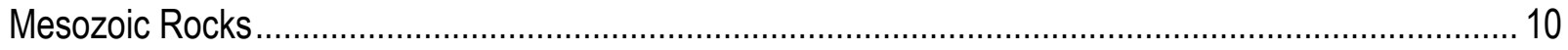

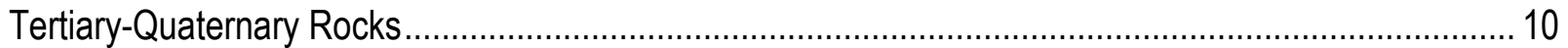

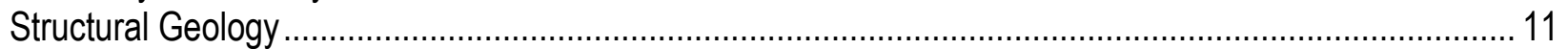

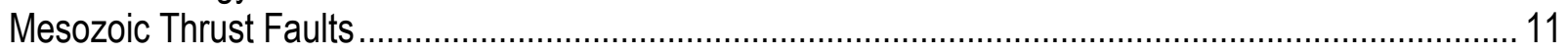

Cenozoic Magmatism, Strike-slip Faults, Normal Faults, and Basin Development ............................... 12

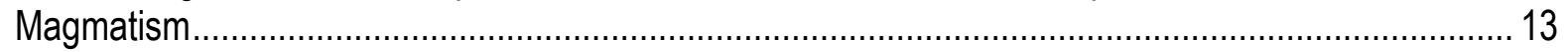

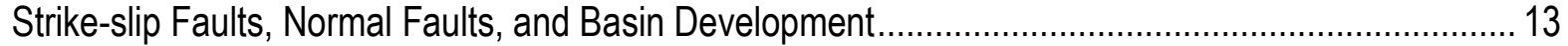

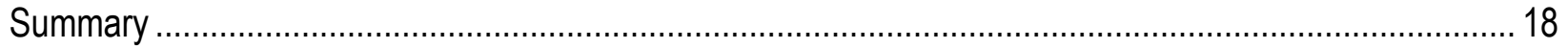

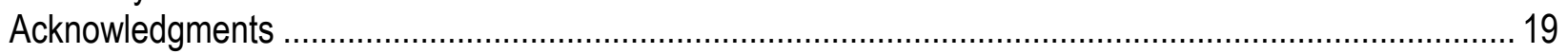

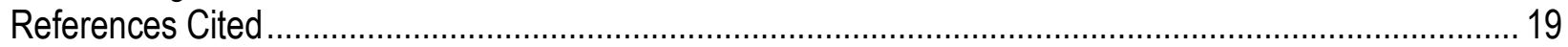

\section{Figures (on Plate 1)}

1. Map showing Death Valley, White River, and Colorado flow systems, and study area boundary

2. Index map showing major physiographic features in the study area

3. Location of cross sections and oil wells

4. Isostatic gravity map of the study area

5. Principal structures in the study area

\section{Table (on Plate 1)}

1. Relationship between bedrock units in cross sections and Page and others, 2005a 


\section{Conversion Factors}

Inch/Pound to SI

\begin{tabular}{ccc}
\hline Multiply & By & To obtain \\
\hline Flow rate & \\
\hline acre-foot per year (acre-ft/yr) & 1,233 & cubic meter per year $\left(\mathrm{m}^{3} / \mathrm{yr}\right)$
\end{tabular}

SI to Inch/Pound

\begin{tabular}{lll}
\hline Multiply & By & To obtain \\
\hline & Length & \\
\hline millimeter (mm) & 0.03937 & inch (in.)
\end{tabular}




\title{
Revised Geologic Cross Sections of Parts of the Colorado, White River, and Death Valley Regional Groundwater Flow Systems, Nevada, Utah, and Arizona
}

\author{
By William R. Page, Daniel S. Scheirer, Victoria E. Langenheim, and Mary A. Berger
}

\begin{abstract}
This report presents revisions to parts of seven of the ten cross sections originally published in U.S. Geological Survey Open-File Report 2006-1040. The revisions were necessary to correct errors in some of the original cross sections, and to show new parts of several sections that were extended and (or) appended to the original section profiles. Revisions were made to cross sections $C-C^{\prime}, D-D^{\prime}, E-E^{\prime}, F-F^{\prime}, G-G^{\prime}, I-I^{\prime}$, and $J-J^{\prime}$, and the parts of the sections revised or extended are highlighted below the sections on plate 1 by red brackets and the word "revised", or "extended." Sections not listed above, as well as the interpretive text and figures, are generally unchanged from the original report. Cross section $C-C$ ' includes revisions in the east Mormon Mountains in the east part of the section; $D-D$ ' includes revisions in the Mormon Mesa area in the east part of the section; $E-E$ ' includes revisions in the Muddy Mountains in the east part of the section; $F-F$ ' includes revisions from the Muddy Mountains to the south Virgin Mountains in the east part of the section; and $J-J$ includes some revisions from the east Mormon Mountains to the Virgin Mountains. The east end of $G-G$ ' was extended about $16 \mathrm{~km}$ from the Black Mountains to the southern Virgin Mountains, and the northern end of $I-I$ ' was extended about $45 \mathrm{~km}$ from the Muddy Mountains to the Mormon Mountains, and revisions were made in the Muddy Mountains part of the original section.

This report contains 10 interpretive cross sections and an integrated text describing the geology of parts of the Colorado, White River, and Death Valley regional groundwater flow systems in Nevada, Utah, and Arizona. The primary purpose of the report is to provide geologic framework data for input into a numerical groundwater model. Therefore, the stratigraphic and structural summaries are written in a hydrogeologic context.

The oldest rocks (basement) are Early Proterozoic metamorphic and intrusive crystalline rocks that are considered confining units because of their low permeability. Late Proterozoic to Lower Cambrian clastic units overlie the crystalline rocks and are also considered confining units within the regional flow systems. Above the clastic units are Middle Cambrian to Lower Permian carbonate rocks that are the primary aquifers in the flow systems. The Middle Cambrian to Lower Permian carbonate rocks are overlain by a sequence of mainly clastic rocks of late Paleozoic to Mesozoic age that are mostly considered confining units, but they may be permeable where faulted.

Tertiary volcanic and plutonic rocks are exposed in the northern and southern parts of the study area. In the Clover and Delamar Mountains, these rocks are highly deformed by north- and
\end{abstract}


northwest-striking normal and strike-slip faults that are probably important conduits in transmitting groundwater from the basins in the northern Colorado and White River flow systems to basins in the southern part of the flow systems.

The youngest rocks in the region are Tertiary to Quaternary basin-fill deposits. These rocks consist of middle to late Tertiary sediments consisting of limestone, conglomerate, sandstone, tuff, and gypsum, and younger Quaternary surficial units consisting of alluvium, colluvium, playa deposits, and eolian deposits. Basin-fill deposits are both aquifers and aquitards.

The rocks in the study area were complexly deformed by episodes of Mesozoic compression and Cenozoic extensional tectonism. Some Cretaceous thrust faults and folds of the Sevier orogenic belt form duplex zones and define areas of maximum thickness for the Paleozoic carbonate rocks. Cenozoic faults are important because they are the primary structures that control groundwater flow in the regional flow systems.

\section{Introduction}

The 10 geologic cross sections (pl. 1) were constructed to better understand the hydrogeologic framework for parts of the Colorado, White River, and Death Valley regional groundwater flow systems in southern Nevada, southwestern Utah, and northwestern Arizona. The main purpose of the cross sections is to provide the National Park Service with geologic framework data for input into a numerical groundwater model. Rapid urbanization and commercial development in the region has increased demand for water from surface-water sources and from local and regional aquifers in these flow systems. As a result, the geology in the area needs to be defined to assist in understanding the complex hydrologic processes that govern groundwater recharge, movement, storage, and discharge.

The study area includes part of the Colorado groundwater flow system (Harrill and Prudic, 1998), the southern part of the White River groundwater flow system (Eakin, 1964, 1966; Thomas and Welch, 1984; and Kirk, 1987), and the eastern part of the Death Valley groundwater flow system (Winograd and Thordarson, 1975; Laczniak and others, 1996; Harrill and Prudic, 1998; D'Agnese and others, 2002; Workman and others, 2002a, 2002b) (fig. 1). The White River flow system is a subset of the Colorado flow system (fig. 1).

The principal discharge for the White River flow system is Muddy River springs (Dettinger and others, 1995) (fig. 2), a series of springs that discharge 36,000 ac-ft/yr to form the Muddy River. Movement of groundwater in the study area is generally southward as indicated by potentiometric maps based on water levels in wells (Thomas and others, 1986; Wilson, 2001). The flow is driven by the hydraulic head parallel to the southward topographic gradient.

Aquifers in the flow systems consist of Paleozoic carbonate rocks, volcanic rocks, and basin-fill sediments (Plume and Carlton, 1988; Dettinger and others, 1995; Prudic and others, 1995; Burbey, 1997; Harrill and Prudic, 1998). The importance of the Paleozoic carbonate-rock aquifer to the flow systems that cover much of southern Nevada and adjacent States is so significant that many regional hydrologic reports have focused on the distribution and features of this aquifer (Dettinger and others, 1995; Burbey, 1997; Wilson, 2001).

\section{Methods}

The 10 interpretive cross sections (pl. 1, fig. 3) were hand drawn at 1:250,000-scale using Page and others (2005a) as a geologic base. Many of the units shown in the cross sections are combined from two or more units from the map. This generalization was necessary to portray 
stratigraphic relations appropriately for the cross section scale. Table 1 shows the relationship between the cross section bedrock units in this report and those in Page and others (2005a). The hand-drawn sections were scanned and converted to digital vector files. The topographic profiles were made using a 90 meter Digital Elevation Model. Most of the sections $\left(A-A^{\prime}, B-B^{\prime}, C-C^{\prime}\right.$, $D-D^{\prime}, E-E^{\prime}$, and $G-G^{\prime}$ ) are oriented east-west (fig. 3), perpendicular to major structures in the study area. The east-west sections on plate 1 were hung on longitude $114^{\circ} 40^{\prime} 00^{\prime \prime}$ as a reference line (fig. 3) to visually extrapolate the geology between the section lines in a north-south progression.

A systematic unit color scheme was applied to the cross sections for a broad translation of geologic units into hydrostratigraphic units. Proterozoic and Lower Cambrian confining units are shades of brown and orange; Middle Cambrian to Lower Permian carbonate aquifer rocks in shades of blue; upper Paleozoic and Mesozoic confining units are shades of green; Cenozoic volcanic and intrusive rocks are shades of pink and red, respectively; and Tertiary to Quaternary basin-fill rocks are yellow.

The cross sections integrate data from existing maps and reports, geophysical investigations, and well data, and are progressively more interpretive with depth because of the lack of data at deeper levels. Page and others (2005a) provided a comprehensive list of geologic map sources and reports used in their compilation and in this study, and they presented detailed lithologic description and thickness of individual units in the map and cross section region. Data from several deep petroleum exploration wells were used to constrain thickness of basin-fill sediments and bedrock geology along several cross sections. These wells were tied into the cross section lines (fig. 3) and include the Texaco Federal \#1 well $\left(C-C^{\prime}\right)$, Mobil Virgin River no. 1-A well $\left(D-D^{\prime}\right)$, and the Grace Petroleum Arrow Canyon \#1 well $\left(G-G^{\prime}\right)$. Stratigraphic and structural data from these wells were from well logs and from Garside and others (1988).

The geology of the Virgin Valley area $\left(B-B^{\prime}, C-C^{\prime}\right.$, and $\left.D-D^{\prime}\right)$ was based on seismicreflection and well data from Bohannon and others (1993), seismic-reflection data from Carpenter and Carpenter (1994), gravity data from Langenheim and others (2000), and magnetic data from Jachens and others (1998). Much of the subsurface geology in the Meadow Valley Wash $\left(A-A^{\prime}, B-B^{\prime}, C-C^{\prime}\right.$, and $\left.D-D^{\prime}\right)$ and Tule Desert $\left(A-A^{\prime}\right)$ areas was based on seismicreflection and gravity data acquired and analyzed by the USGS, and is summarized in Scheirer and others (2006). The subsurface geology in the central part of California Wash $\left(E-E^{\prime}\right.$ and $F-$ $F^{\prime}$ ) was based on Langenheim and others $(2001 \mathrm{~b}, 2002)$. The subsurface geology of Coyote Spring Valley $\left(B-B^{\prime}, C-C^{\prime}, D-D^{\prime}, E-E^{\prime}\right.$, and $\left.F-F^{\prime}\right)$ was partly based on Phelps and others (2000). Cenozoic basin-fill thickness and geometry shown for basins in the western part of the study area (west of Coyote Spring Valley) is based on Blakely and Ponce (2001). Regional and detailed gravity data (fig. 4) were used to constrain Cenozoic basin geometry and depth to crystalline basement in much of the cross section area.

\section{Stratigraphy}

\section{Proterozoic and Paleozoic Rocks}

Early Proterozoic metamorphic and intrusive rocks consist of gneiss, granite, and schist that are about 1.7 Ga (Quigley and others, 2002). These crystalline rocks form both geologic and hydrologic basement and are considered barriers to groundwater flow because of their low permeability. The crystalline rocks may be locally permeable where highly fractured, but fractures in these rocks are generally poorly connected (D'Agnese and others, 1997). Early 
Proterozoic rocks exposed in the Beaver Dam and Virgin Mountains form the eastern boundary of the flow systems $\left(A-A^{\prime}, B-B^{\prime}, C-C^{\prime}, D-D^{\prime}\right.$ and $\left.E-E^{\prime}\right)$. Early Proterozoic rocks also form the core of the Mormon Mountains where they act as a local barrier to groundwater flow (Burbey, 1997) ( $B-B^{\prime}$ and $C-C^{\prime}$ ), although through-going, north-striking faults along the western and eastern Mormon Mountains may provide conduits for some southward groundwater flow through the mountain range.

A north-trending positive gravity anomaly extends from the Meadow Valley Mountains to the central Arrow Canyon Range (fig. 4). We interpret this gravity high to represent a zone of shallow Proterozoic crystalline rocks beneath parts of the Meadow Valley Mountains and Arrow Canyon Range $\left(C-C^{\prime}, D-D^{\prime}\right.$ and $\left.E-E^{\prime}\right)$. Termination of the gravity anomaly south of the central Arrow Canyon Range may be due to the development of duplex zones and thicker Paleozoic rocks in the southern Arrow Canyon and Las Vegas Ranges shown along cross sections $F-F^{\prime}$ and $G-G^{\prime}$ (see Mesozoic Thrust Faults section below).

Late Proterozoic sedimentary rocks in the study area consist of quartzite, conglomerate, sandstone, siltstone, and shale, and they contain subordinate amounts of limestone and dolostone. The Late Proterozoic sedimentary rocks are well cemented, contain minimal pore space, and have low permeability. They were deposited in shallow marine waters along a passive continental margin of what is now western North America (Stewart, 1976; Stewart and Poole, 1972) and represent initial deposits of the Cordilleran miogeocline (Stewart and Poole, 1972; Stewart, 1972, 1976).

Lower Cambrian rocks are predominantly well-cemented, clastic units of quartzite, conglomerate, siltstone, and shale with low permeability. Together, the Lower Cambrian and Late Proterozoic sedimentary rocks form a confining unit in the study area. In the Death Valley groundwater flow system, these rocks are referred to as the lower clastic aquitard (Winograd and Thordarson, 1975), or the lower clastic confining unit (Belcher and others, 2002). These rocks are reported to be nearly impermeable and have low transmissivities based on pumping tests and other hydrologic data in the region (Winograd and Thordarson, 1975). Late Proterozoic clastic units are present mostly in the western part of the study area and they pinch out to the east and are absent in the Mormon, Virgin, and Beaver Dam Mountains, and in the Lake Mead area. In these areas, the lower clastic confining rocks include the Lower Cambrian Tapeats Sandstone and the Lower and Middle Cambrian Bright Angel Shale.

Middle Cambrian through Lower Permian rocks record a significant shift in deposition to predominantly carbonate sedimentation, from mostly clastic sedimentation in pre-Bonanza King (and equivalent units) Late Proterozoic and Cambrian units. The carbonate rocks are predominantly limestone and dolostone and form the regional aquifer (Dettinger and others, 1995). The Middle and Upper Cambrian Bonanza King Formation (and partly equivalent Highland Peak Formation and Muav Limestone) forms the basal part of the carbonate aquifer in the White River, Colorado, and Death Valley groundwater flow systems (Winograd and Thordarson, 1975; Laczniak and others, 1996; Belcher and others, 2002; D'Agnese and others, 2002). Groundwater flow through the carbonate rocks is mostly through fractures and faults. Because the rocks are soluble in groundwater, dissolution features are also important in the development of secondary porosity and permeability. Zones of high transmissivity in the carbonate rock aquifer are indicated by large spring discharge (36,000 ac-ft/yr at Muddy River Springs) in areas of low potentiometric gradient, and by water wells exhibiting extremely high hydraulic conductivity (Dettinger and others, 1995). 
Middle Cambrian through Lower Permian rocks are predominantly carbonate with the exception of the Upper Cambrian Dunderberg Shale Member of the Nopah Formation (70 to 100 $\mathrm{m}$ thick), Middle Ordovician Eureka Quartzite (0 to $120 \mathrm{~m}$ ), Upper Mississippian Chainman Shale (200 to $285 \mathrm{~m}$ ), Upper Mississippian Indian Springs Formation (20 to $60 \mathrm{~m}$ ), and the Lower Permian redbeds $(600 \mathrm{~m})$. The Dunderberg Shale Member, Eureka Quartzite, and Indian Springs Formation are probably not thick enough to form regional confining units, but they may act as confining units locally. The Chainman Shale and Lower Permian redbeds are substantially thicker and may be regional confining units in parts of the study area.

The upper part of the carbonate aquifer in the study area consists of Upper Mississippian and Lower Permian units, including the Bird Spring Formation and partly equivalent Callville Limestone and Pakoon Dolomite. Lower Permian redbeds overlie these formations and represent a shift from predominantly carbonate marine to mostly continental sedimentation, although a few carbonate units lie above the Lower Permian redbeds, including the Lower Permian Kaibab and Toroweap Formations, and the Lower Triassic Virgin Limestone Member of the Moenkopi Formation. Continental sedimentation predominated through the Mesozoic and into the lower Tertiary.

\section{Late Proterozoic-Paleozoic Facies Belts}

Late Proterozoic-Paleozoic rock units are separated geographically into facies belts even though they may be partly or entirely correlative. This is because facies changes prevent exact correlations between areas, and different names have been applied to rocks of the same age. In the study area, Late Proterozoic-Paleozoic rocks can be broadly subdivided into western, central, and eastern facies belts (Page and others, 2005a).

Rocks in the western belt include Late Proterozoic through Devonian units deposited as part of the Cordilleran miogeocline in offshore carbonate shelf and intertidal depositional settings, and an overlying Mississippian to Permian sequence deposited mostly in a carbonate platform depositional setting. These rocks are exposed as far east as the Las Vegas Range, Arrow Canyon Range, Meadow Valley Mountains, and Delamar Mountains (fig. 2). From oldest to youngest, these rocks include the following formations: Johnnie Formation (Late Proterozoic); Stirling Quartzite (Late Proterozoic) and Wood Canyon Formation (Late Proterozoic and Lower Cambrian) and their equivalent, the Prospect Mountain Quartzite; Carrara Formation (Lower and Middle Cambrian) and northern equivalents, Chisholm Shale (Middle Cambrian), Lyndon Limestone (Middle Cambrian), and Pioche Shale (Lower and Middle Cambrian); Bonanza King (Middle and Upper Cambrian) and partly equivalent Highland Peak Formation (Middle Cambrian); Nopah Formation (Upper Cambrian); Pogonip Group (Upper Cambrian to Middle Ordovician); Eureka Quartzite (Middle Ordovician); Ely Springs Dolomite (Upper Ordovician); Laketown Dolomite (Lower Silurian); Sevy Dolomite (Lower Devonian); Simonson Dolomite (Middle Devonian); Guilmette Formation (Middle and Upper Devonian) and the partly equivalent Sultan Limestone (Middle Devonian to Lower Mississippian); Monte Cristo Group (Lower and Upper Mississippian) and the partly equivalent Joana Limestone (Lower Mississippian); Chainman Shale (Lower and Upper Mississippian) and Scotty Wash Quartzite (Upper Mississippian); and Bird Spring Formation (Upper Mississippian to Lower Permian).

The eastern facies belt includes cratonic platform rocks of the Colorado Plateau region exposed in the Beaver Dam and Virgin Mountains, and in the Lake Mead area including Frenchman Mountain (table 1). The rocks are mostly shallow marine sediments deposited in near-shore, intertidal, shoreline, and continental settings. The facies belt is characterized by a large magnitude unconformity separating Middle Devonian from Upper Cambrian rocks. The 
cratonic sequence, or eastern facies belt, includes (from oldest to youngest): Tapeats Sandstone (Lower Cambrian); Bright Angel Shale (Lower and Middle Cambrian); Muav Limestone (Middle Cambrian); Nopah Formation (Upper Cambrian); Temple Butte Formation (Middle? and Upper Devonian); Redwall Limestone (Lower and Upper Mississippian); and Callville Limestone (Pennsylvanian) and Pakoon Dolomite (Lower Permian). The central facies belt includes rocks that are transitional between the eastern and western belts; these rocks are exposed in the Muddy Mountains, Mormon Mountains, and Tule Springs Hills (fig. 2).

The thickness of Middle Cambrian to Lower Permian carbonate rocks that form the regional aquifer decreases dramatically across the belts from west to east over a distance of about $100 \mathrm{~km}$; from a maximum of about $7 \mathrm{~km}$ thick in the western belt to less than $2 \mathrm{~km}$ thick in the eastern belt. Whereas thinning resulted from erosion of individual units along major unconformities and stratigraphic thinning of individual units toward the craton, the greatest thickness variation across the belts is because the Paleozoic rocks were telescoped into a narrower zone during Mesozoic thrusting.

\section{Mesozoic Rocks}

Mesozoic rocks are predominantly continental clastic units consisting of conglomerate, sandstone, siltstone, mudstone, shale, and gypsum, but they also include minor limestone and dolostone. These rocks are exposed mostly in the eastern parts of the study area and were deposited in fluvial, lacustrine, eolian, and marginal marine environments, and they include Triassic, Jurassic, and Cretaceous units. The Mesozoic rocks have low permeability compared with the Paleozoic carbonate rocks because of their high proportion of clastic material. They are generally considered confining units, but they may be permeable where highly fractured. Units containing large amounts of shale and mudstone, such as in the Triassic formations, generally have low permeability. The Jurassic Navajo Sandstone in the Utah part of the study area is an aquifer (Heilweil and others, 2002), but in other parts of southern Nevada, such as in Las Vegas Valley, the Jurassic Aztec Sandstone generally has low permeability. This example illustrates the variability in hydrologic properties of the Mesozoic rocks.

\section{Tertiary-Quaternary Rocks}

Tertiary and Quaternary rocks in the cross sections are mostly basin-fill deposits, which consist of alluvium and colluvium, playa deposits, eolian deposits, spring discharge deposits, and landslide breccias of Miocene to Holocene age. Older basin-fill rocks include the Miocene and Pliocene Muddy Creek Formation and equivalent units in the Lake Mead area, and the Oligocene and Miocene Horse Spring Formation and equivalent units. The Muddy Creek Formation is mostly lacustrine and fluvial mudstone, tuffaceous sandstone, gypsum, halite, and conglomerate. The Horse Spring Formation consists of fluvial and lacustrine rocks, comprised of tuffaceous sandstone, tuff, conglomerate, siltstone, mudstone, limestone, and gypsum.

Basin-fill rocks in the study area are both aquifers and aquitards. Basin-fill deposits in the Mesquite basin of the Virgin Valley reach maximum thicknesses of about 8 to $10 \mathrm{~km}$ (Langenheim and others, 2001a, 2000). In the Mesquite, Nev., area, the Muddy Creek Formation is the main aquifer (Johnson and others, 2002; Dixon and Katzer, 2002), where it consists of gravel, sand, silt, and clay, and is moderately deformed by high-angle normal faults.

Dettinger and others (1995) hypothesized that Muddy River Springs partly exist due to thick basin deposits of lower Meadow Valley Wash basin which may form a groundwater barrier to eastward flow from the springs (see cross section $D-D^{\prime}$ ). The Muddy Creek Formation is 
widely exposed in this basin, and unlike the Muddy Creek in the Virgin Valley area, the formation is mildly deformed and is mostly low-permeability lacustrine clay and silt.

Unit Tv in the cross sections includes volcanic rocks of Oligocene to Pliocene age. Most of the volcanic rocks are ash-flow tuffs erupted from calderas, but stratovolcanoes were locally present. These rocks also include basalt and lava flows. In the Delamar and Clover Mountains, the volcanic rocks range from several hundred to several thousand meters thick. Intracaldera tuffs are generally thicker than outflow tuffs. Unit Ti consists of granitic intrusive rocks that generally are the source plutons for the volcanic units in unit Tv.

\section{Structural Geology}

The physiography of the study area reflects late Mesozoic and Cenozoic structural events that produced a Cretaceous fold-and-thrust belt that was subsequently disrupted by Cenozoic extensional and transform tectonics, and accompanying intrusive and volcanic activity.

\section{Mesozoic Thrust Faults}

Major thrust faults in the study area include the Muddy Mountain and Gass Peak thrusts. The Muddy Mountain thrust is exposed in the Muddy Mountains; several equivalent thrusts extend northward (Hintze and Axen, 2001) including: the Glendale thrust in the Glendale, Nev., area; Mormon thrust in the Mormon Mountains; Tule Spring thrust in the Tule Springs Hills, Nevada; and the Square Top Mountain thrust in the northern Beaver Dam Mountains in southwest Utah (fig. 5).

The Gass Peak thrust (Guth, 1980, 1981, 1990) in the Sheep Range is west of and at a structurally higher level than the Muddy Mountain and equivalent thrusts (fig. 5). The thrust faults strike north to northeast and are east to southeast vergent structures of Sevier orogenic belt (Armstrong, 1968; Fleck, 1970). The Muddy Mountain and equivalent thrusts are the frontal thrusts of the Sevier orogenic belt in southern Nevada and southwestern Utah. The Muddy Mountain thrust is reported to be late Albian to Cenomanian(?) in age (Bohannon, 1983; Carpenter and Carpenter, 1994; Fleck and Carr, 1990). Several intermediate thrusts are between the Muddy Mountain (and equivalent thrusts) and Gass Peak thrusts. These include the Delamar thrust in the southern Delamar Mountains $\left(B-B^{\prime}\right)$ (Page, 1990), the Meadow Valley and Vigo thrusts in the Meadow Valley Mountains $\left(B-B^{\prime}\right)$ (Pampeyan, 1993), and the Dry Lake thrust and other unnamed thrusts in the Arrow Canyon and Dry Lake Ranges $\left(D-D^{\prime}, F-F^{\prime}\right.$, and $\left.G-G^{\prime}\right)$ (Page, 1992; Page and Dixon, 1992). The Summit Willow Tank thrust is a secondary thrust fault below the Muddy Mountain thrust in the Muddy Mountains $\left(E-E^{\prime}\right.$ and $\left.F-F^{\prime}\right)$ (Bohannon, 1983).

A commonly accepted model for thrusts in the Sevier belt, which we have conceptually applied to the cross sections, is that of a ramp-flat, decollemont geometry, where thrusts are flat at depth along a basal decollement and detach to ramp at certain stratigraphic levels. We follow Guth (1980) in the interpretation of a flat-ramp-flat geometry for the Gass Peak thrust with decollement zones near the base of the Late Proterozoic-Lower Cambrian sequence (Guth, 1980; fig. 1, case 1, p. 151). East of the Gass Peak thrust, the regional decollement forms an extensive hanging-wall flat near the base of the Middle and Upper Cambrian Bonanza King Formation as indicated by exposure of these rocks at the base of hanging-wall ramps and flats in the Muddy Mountain $\left(E-E^{\prime}, F-F^{\prime}\right.$, and $\left.G-G^{\prime}\right)$, Mormon $\left(B-B^{\prime}\right.$ and $\left.C-C^{\prime}\right)$, Tule Spring $\left(A-A^{\prime}\right)$, and Delamar $\left(B-B^{\prime}\right)$ thrust faults. The eastward transition to a decollement at the base of the Bonanza King Formation is probably controlled by the west to east pinch out of the Late Proterozoic clastic units against the craton (Sweetkind and others, 2001); the pinch out is in a zone between the 
Sheep Range and the Arrow Canyon Range/Meadow Valley Mountains because Late Proterozoic rocks at the base of the sedimentary sequence are absent in the Mormon Mountains and Tule Springs Hills, and rocks of the Middle and Lower Cambrian Bright Angel Shale and Lower Cambrian Tapeats Sandstone rest directly on Early Proterozoic crystalline basement.

Duplex zones in the Paleozoic carbonate rocks are interpreted along the Dry Lake and Muddy Mountain thrusts $\left(F-F^{\prime}\right.$ and $\left.G-G^{\prime}\right)$. These duplex zones define areas of maximum thickness for the Paleozoic carbonate rocks in the region because the Paleozoic section is essentially repeated along the thrusts. In cross section $G-G^{\prime}$, these rocks are interpreted to be greater than $7 \mathrm{~km}$ thick based on logs from the Grace Petroleum Arrow Canyon no. 1 well. In this well, an upper thrust fault is interpreted at about 2,288 $\mathrm{m}$ depth where rocks of the Cambrian Carrara Formation are in the upper plate above rocks of the Cambrian Bonanza King Formation in the lower plate. A lower thrust fault occurs at about 2,800 $\mathrm{m}$ depth where rocks of the Bonanza King Formation in the upper plate are above rocks of the Mississippian-Permian Bird Spring Formation in the lower plate, thus repeating the Paleozoic section from the Bird Spring Formation downward. We interpret the upper fault as the Dry Lake thrust and the lower fault as the Muddy Mountain thrust $\left(G-G^{\prime}\right)$. The zone between the two faults is characterized by complexly repeated Cambrian units indicating horst blocks and (or) imbrication structures, features commonly associated with thrust fault zones.

Burbey (1997) suggested that Late Proterozoic-Lower Cambrian clastic confining units in the upper plate of the Gass Peak thrust may restrict eastward groundwater flow from the Sheep Range and areas to the west. The upper plate confining units are thrust over Mississippian to Permian rocks of the Bird Spring Formation in the lower plate as shown in cross sections $F-F^{\prime}$ and $G-G^{\prime}$. North of $F-F^{\prime}$, however, the Gass Peak thrust loses throw and juxtaposes mainly Paleozoic carbonate rocks in upper and lower plates $\left(B-B^{\prime}\right)$.

The Muddy Mountain thrust in the Muddy Mountains juxtaposes Paleozoic carbonate rocks in the upper plate against Mesozoic and Paleozoic rocks in the lower plate $\left(G-G^{\prime}\right)$; such a relationship suggests that the less permeable Mesozoic rocks below the thrust may act as a groundwater flow barrier, and the thrust has been characterized as a barrier in local groundwater models. Although the lower plate rocks may act as a barrier in localized zones along strike, we think that overprinting of the thrust by Cenozoic faults (Langenheim and others, 2002) provides linkage between rocks in the upper and lower plates, allowing for some groundwater flow across the thrust. This example may apply to other Mesozoic thrust faults in the map area, especially where the thrusts are highly modified by younger Cenozoic extensional faults.

Mesozoic thrusts have been reactivated by normal faults during Cenozoic extension in parts of the study area. The Delamar thrust has been reactivated by high-angle normal faults in the southern Delamar Mountains (Page, 1990). Guth (1990) reported that parts of the Gass Peak thrust may have been reactivated by Cenozoic normal faults, and structural relations illustrated in cross section $B-B^{\prime}$ suggest extensional Cenozoic reactivation on the thrust based on Tertiary volcanic rocks downfaulted on the thrust in the northern Sheep Range. Axen and others (1990) discussed extensional Cenozoic reactivation of the Tule Spring thrust in the Tule Springs Hills.

\section{Cenozoic Magmatism, Strike-slip Faults, Normal Faults, and Basin Development}

Cenozoic tectonics affected the rocks in the study area and includes volcanism and plutonism, normal and strike-slip faulting, and basin development. Cenozoic faults are important because they represent the last major phase of deformation that affected the rocks in the region, and they provide the fractures and faults that control groundwater flow through the Paleozoic carbonate aquifer. Quaternary faults are present in parts of the study area, and faulting is 
currently active in some areas such as in the Pahranagat shear zone. These younger faults may be especially important in groundwater flow because younger faults and fractures tend to be more open than in older fault systems (Dettinger and others, 1995), and in many cases, they have reactivated older fault zones.

\section{Magmatism}

The northern part of the study area is characterized by numerous Oligocene and Miocene volcanic rocks, mainly ash-flow tuffs erupted from calderas, but also some lava flows and granitic plutons. The southern limit of these rocks occurs at about latitude $37^{\circ}$, just north of the Mormon Mountains and Tule Springs Hills, and the negative isostatic gravity anomalies in the northern part of figure 4 reflect low-density volcanic rocks in the Clover Mountains (Scheirer and others, 2006). Volcanic rocks are also exposed in the southeast part of the study area in the southern Virgin Mountains, Black Mountains, and Lake Mead area. These rocks include Miocene andesitic volcanic rocks and calc-alkaline plutons.

The volcanic rocks in the northern part of the study area were erupted mainly from the Caliente caldera complex (Rowley and others, 1995) in the Delamar and Clover Mountains, and the Kane Wash caldera complex (Scott and others, 1995) in the Delamar and Meadow Valley Mountains (fig. 5). The Caliente caldera complex in the Clover Mountains is highly deformed by north- and northwest-striking normal and strike-slip faults (Page and others, 2005a) that may be important conduits in transmitting ground water from basins in the northern part of the Colorado flow system to basins in the southern part of the flow system.

\section{Strike-slip Faults, Normal Faults, and Basin Development}

Major strike-slip fault zones include the northeast-striking, left-lateral Pahranagat shear zone, Kane Springs Wash fault zone, and Lake Mead fault zone, and the northwest-striking, right-lateral Las Vegas Valley shear zone (fig. 5). These fault zones represent transfer or accommodation zones that separate structural blocks within the study area that have undergone different rates and amounts of extension (Guth, 1981; Wernicke and others, 1982; Duebendorfer and Black, 1992; Rowley, 1998). Strike-slip faults are denoted on the cross sections with the letters " $T$ " and "A", indicating relative fault block movement toward or away from the viewer, respectively (see plate symbol explanation).

The Pahranagat shear system is a zone of steeply northwest-dipping faults that shows evidence of dip-slip and strike-slip offset (fig. 5). Tschanz and Pampeyan (1970) estimated about 6 to $9 \mathrm{~km}$ of left-lateral displacement on the shear system. Modern fault scarps and fissures in alluvial deposits in southern Delamar Valley (Swadley, 1995), and current seismicity on faults in the shear system (Rogers and others, 1987) indicate that it is active. Strands of the Pahranagat shear system join together and merge with north-striking range front faults bounding the northern Delamar Mountains to the north, and the southern Delamar Mountains and the Sheep Range to the south (Page and others, 2005a). Cross section $B-B^{\prime}$ transects the southern part of the shear zone, and displays a series of closely-spaced, northwest-dipping faults offsetting primarily Late Proterozoic and Paleozoic rocks. The volcanic rocks in $B-B^{\prime}$ are thin near the southern limit of their exposure, but they thicken to the north within the shear zone (Page and others, 2005a).

The Kane Springs Wash fault zone (fig. 5) is a left-lateral fault system that has about 7 to $11 \mathrm{~km}$ of displacement based on offset of the Kane Springs Wash caldera (Harding and others, 1995). Northeast-striking faults of the Kane Springs Wash fault zone merge into the northstriking range front fault system on the west side of the Meadow Valley Mountains. In cross 
section $A-A^{\prime}$, the Kane Springs Wash fault zone is $3 \mathrm{~km}$ wide and cuts mainly volcanic and plutonic rocks of the Kane Wash caldera complex. Southward $\left(B-B^{\prime}\right)$, the fault zone is about 5 $\mathrm{km}$ wide and cuts mainly Paleozoic carbonate rocks. Early Proterozoic crystalline rocks are interpreted to be present at shallow depths (less than $4 \mathrm{~km}$ ) near where the fault zone intersects $B-B^{\prime}$, based on surface exposure of older Paleozoic rocks (Cambrian) and on regional gravity data (fig. 4). Quaternary faulting has been reported along some strands of the Kane Springs Wash fault zone in Kane Springs Wash (Swadley and others, 1994).

The northwest-striking Las Vegas Valley shear zone (LVVSZ) (fig. 5) is a largemagnitude, right-lateral, strike-slip fault zone that formed during Cenozoic extension (Page and others, 2005b). The shear zone truncates the southern Las Vegas, Sheep, Desert, and Pintwater Ranges, and extends for nearly $150 \mathrm{~km}$ from the Lake Mead area to Mercury, Nevada. The LVVSZ played a significant role in the tectonic development of Las Vegas Valley (Page and others, 2005b). The effects of the LVVSZ include oroflexural bending and offset of major Mesozoic thrust faults and folds. Offset of Mesozoic thrust faults across Las Vegas Valley indicate $48 \pm 7 \mathrm{~km}$ of right-lateral separation (Wernicke and others, 1988); this estimate includes bending of the Las Vegas Range. Paleomagnetic data (Sonder and others, 1994; Nelson and Jones, 1987) indicated a 20-km-wide zone of clockwise rotation as great as $100^{\circ}$ in rocks as young as $13.5 \mathrm{Ma}$ adjacent to the LVVSZ. The paleomagnetic data, along with other structural data, bracket the principal period of movement along the LVVSZ between 14 and $8.5 \mathrm{Ma}$ (Duebendorfer and Black, 1992; Duebendorfer and Simpson, 1994).

Two strands of the LVVSZ are shown in $H-H^{\prime}$ in the Frenchman Mountain area. The northern strand is concealed by basin-fill sediments between the Dry Lake Range and Frenchman Mountain, and it is shown as a north-dipping fault that juxtaposes a thick section of Paleozoic rocks in the hanging wall against Proterozoic crystalline rocks beneath Frenchman Mountain in the footwall. The southern strand of the LVVSZ juxtaposes cratonic Paleozoic rocks of Frenchman Mountain in the footwall of the fault against presumably thicker, cratonic margin Paleozoic rocks and Tertiary volcanic rocks concealed beneath basin-fill deposits in the hanging wall.

The Lake Mead fault zone (LMFZ) (fig. 5) is a major northeast-striking, left-lateral fault system consisting of about four major fault strands that form a crustal boundary separating the Great Basin to the north from the lower Colorado extensional corridor to the south (Anderson, 1973; Anderson and others, 1994; Bohannon, 1983). The major strands of the fault zone bound structural blocks which have undergone large lateral translations. For example, the Frenchman Mountain block is interpreted to have been displaced $65 \mathrm{~km}$ southwestward during Miocene extension (Anderson and others, 1994). Rocks in the lower Colorado extensional corridor (Faulds and others, 2001) consist largely of Proterozoic crystalline rocks, and Tertiary volcanic and plutonic rocks. Paleozoic and Mesozoic rocks are present in isolated blocks on the flanks of crystalline basement uplifts (see east end of $F-F^{\prime}$ ). Faults of the LMFZ are shown in the eastern parts of cross sections $F-F^{\prime}$ and $G-G^{\prime} . F-F^{\prime}$ shows the LMFZ juxtaposing Mesozoic and Paleozoic rocks of the Muddy Mountains in the hanging wall against shallow Proterozoic crystalline rocks in the footwall in the South Virgin Mountains. $G-G^{\prime}$ shows near-vertical strands of the LMFZ juxtaposing Paleozoic and Mesozoic rocks in the Muddy Mountains against Proterozoic crystalline rocks and Tertiary volcanic and plutonic rocks in the Lower Colorado extensional corridor.

Strike-slip faults are reported in the Tule Springs Hills and East Mormon Mountains (Anderson and Barnhard, 1993; Hintze and Axen, 2001; Axen and others, 1990). The East Tule 
Desert fault (fig. 5) is a left-lateral, strike-slip fault that bounds the west flank of the Tule Springs Hills. In cross section $A-A^{\prime}$ Paleozoic and Mesozoic rocks of the Tule Spring autochthon are offset along the fault, and the downthrown side forms Tule Desert, a shallow basin with less than $500 \mathrm{~m}$ of Cenozoic basin-fill deposits (Scheirer and others, 2006). The Sams Camp and Carp Road faults (fig. 5) are probably equivalent to the East Tule Desert fault, and extend farther south along the East Mormon Mountains. These faults juxtapose Paleozoic rocks in the hanging wall against a footwall horst cored by Proterozoic crystalline rocks $\left(B-B^{\prime}\right)$. At the south end of the East Mormon Mountains, the Carp Road fault bends southwestward where it merges with the Davidson Peak fault, an east-striking transverse zone composed of highly folded Paleozoic and Mesozoic rocks (fig. 5), and then bends south to bound the west flank of the southern Mormon Mountains (along Candy Peak; $D-D^{\prime}$; fig. 2). Anderson and Barnhard (1993) interpreted that the large sinistral displacements along these strike-slip faults are kinematically linked to major uplifts and depressions in the Mormon Mountain area that formed during Miocene extension. Alternatively, Axen and others (1990) interpreted that these faults are kinematically linked to the large-magnitude Cenozoic extension on the Tule Spring and Mormon Peak detachment faults (see below).

Locally before $10 \mathrm{Ma}$, normal block-faulting created north-trending ranges and basins to form the present-day physiography that characterizes the Basin and Range province. These faults, which define the Pintwater, Desert, Sheep, and Arrow Canyon Ranges, and Delamar and Meadow Valley Mountains (fig. 5), are especially prominent in the western part of the study area. These range-bounding faults are predominantly normal faults, but some of them have an oblique-slip component, especially along their margins with transverse structures such as the Las Vegas Valley shear zone and the Pahranagat shear zone. The range-front fault on the west side of the Desert Range juxtaposes Late Proterozoic-Lower Cambrian confining units and overlying Lower Cambrian to Devonian carbonate units in the hanging wall against shallow Proterozoic crystalline and overlying Late Proterozoic confining units in the footwall $\left(C-C^{\prime}\right.$ and $\left.D-D^{\prime}\right)$.

The range front fault zone along the west flank of the Sheep Range is characterized by westward tilted blocks of Late Proterozoic and Paleozoic units along a series of west-dipping normal faults extending to the Desert Range $\left(C-C^{\prime}, D-D^{\prime}\right.$, and $\left.G-G^{\prime}\right)$. Guth (1981) estimated 44 percent extension across this area based on restoration of rotated beds in the fault blocks. Faults in this region are interpreted to have a listric geometry to account for tilting, and Wernicke and others (1988) suggested that these faults may sole into a deep regional detachment fault of uncertain depth. Guth (1981) discussed the possibility that a regional detachment may merge with the Mesozoic thrust systems, but we interpret that the normal faults offset the thrusts at depth (rather than merging with them) to produce an irregular basement-sedimentary rock interface.

Range front faults on the west flanks of the southern Delamar Mountains, Meadow Valley Mountains, and Arrow Canyon Range were important in the development of Coyote Spring Valley $\left(B-B^{\prime}, C-C^{\prime}, D-D^{\prime}\right.$, and $\left.F-F^{\prime}\right)$. In general, these fault systems consist of a series of steep, west-dipping normal faults that down-drop Paleozoic strata westward in a step-like pattern (Page, 1998; Page and others, 1990; Page and Pampeyan, 1996). Displacement on individual faults is generally less than $1 \mathrm{~km}$, and cumulative displacements may be as much as $2 \mathrm{~km}$ (Page, 1998; Page and others, 1990). Phelps and others (2000) interpreted the subsurface location of some of these faults based on gravity data. Their study also indicates that Cenozoic basin-fill deposits probably reach a maximum thickness of about 1 to $1.5 \mathrm{~km}$ in Coyote Spring Valley. 
A prominent high-angle normal fault on the west side of the Mormon Mountains is referred to here as the Meadow Valley Wash (MVW) fault (fig. 5). The fault structurally controls Meadow Valley Wash and probably was important in accommodating Miocene uplift of the Mormon Mountains (also see $B-B^{\prime}$ and $C-C^{\prime}$ ). Along $A-A^{\prime}$ the fault juxtaposes Paleozoic and Mesozoic rocks of the Tule Spring autochthon in the footwall against Cenozoic basin-fill deposits and underlying Paleozoic rocks of the Tule Spring allochthon in the hanging wall. $B-B^{\prime}$ and $C-C^{\prime}$ show the MVW fault juxtaposing a thick sequence of Paleozoic rocks of the Mormon thrust allochthon in the hanging wall against Proterozoic crystalline rocks in the footwall. South of $C-C^{\prime}$, the nature of the MVW fault is unknown, although we interpret it to merge with the system of strike-slip faults on the west flank of the southern Mormon Mountains to form the east boundary of lower Meadow Valley Wash basin. Seismic-reflection data (Scheirer and others, 2006) in the northern part of Meadow Valley Wash (in the area of $A-A^{\prime}$ ) suggest the MVW fault is a high-angle normal fault.

The MVW fault may be a conduit for north-south groundwater flow beneath Meadow Valley Wash, but the upthrown block of Proterozoic crystalline confining units in the Mormon Mountains probably forms a barrier to eastward groundwater flow across the mountain range. Abundant paleo-spring carbonate deposits fill faults and fractures in bedrock units on the east and south flanks of the Meadow Valley Mountains and in Tertiary basin-fill sediments in Meadow Valley Wash (Page and Pampeyan, 1996; Schmidt, 1994; Schmidt and Dixon, 1995). These spring carbonate features are indicative of groundwater discharge and the existence of a past groundwater flow path through the thick sequence of Paleozoic carbonate rocks concealed beneath the eastern Meadow Valley Mountains and Meadow Valley Wash.

Seismic-reflection and gravity data (Scheirer and others, 2006) indicate that Meadow Valley Wash is partitioned into a series of fault-controlled basins. The deepest basin is between Moapa and Rox, Nev., (figs. 2 and 4). Cenozoic basin-fill deposits in the basin may be 2 to $3 \mathrm{~km}$ thick in the central part of the basin, and they are complexly deformed by folds and faults. Basinfill surface exposures in this area are also complexly deformed. The Permian Kaibab Limestone crops out near Rox $\left(C-C^{\prime}\right)$, indicating a bedrock ridge constricts Meadow Valley Wash and bounds a shallower basin to the north. A drill hole in the northern basin (just north of Rox) bottomed out in basin-fill deposits at $730 \mathrm{~m}$, and seismic-reflection data suggest Cenozoic basinfill deposits may be up to $1 \mathrm{~km}$ thick (Scheirer and others, 2006). The northernmost basin of Meadow Valley Wash is between Carp and Leith (fig. 2). Cenozoic basin-fill deposits are interpreted to be 1 to $2 \mathrm{~km}$ thick in this basin (Scheirer and others, 2006), and the main basin structure is controlled by the MVW fault.

Wernicke and others (1985) and Axen and others (1990) interpreted that three stacked, west-dipping, low-angle normal (detachment) faults (Mormon Peak, Tule Springs, and Castle Cliff detachments) between the Meadow Valley Mountains and the Beaver Dam Mountains are the first order Cenozoic extensional structures in the region. Axen and others (1990) interpreted the Castle Cliff detachment as the lowest-level fault that projects westward in the subsurface beneath Tule Springs Hills as a continuation of the Castle Cliff fault exposed on the west flank of the Beaver Dam Mountains. The Tule Springs detachment is the intermediate fault interpreted by Axen and others (1990) as a breakaway zone on the west flank of the East Mormon Mountains to project westward below the main part of the Mormon Mountains. Wernicke and others (1985) interpreted the Mormon Peak detachment as the highest-level fault exposed in the Mormon Mountains to project westward beneath the Meadow Valley Mountains. Wernicke and others (1985) and Axen and others (1990) interpreted these as large-magnitude extensional faults that 
root into crystalline basement and were activated from west to east by processes of simple uniform shear.

Anderson and Barnhard (1993) noted low-angle normal faults in the area but on the basis of fault kinemetics and careful geologic mapping, they challenged the idea that these detachments had large lateral extent, and, alternatively, they viewed detachments as localized structures that accommodated strain associated with extreme vertical uplift. Carpenter and Carpenter (1994) also downplayed the role of detachments as first order Cenozoic extensional structures on the basis of seismic-reflection data and geologic mapping, and they reinterpreted many of the detachments in the Mormon Mountains as localized gravity-slide slip-surfaces. The cross sections in this report are conceptually in agreement with Anderson and Barnhard (1993) and Carpenter and Carpenter (1994), and portray detachments as more localized structures and high-angle normal and strike-slip faults as the first order extensional structures in this region.

The Piedmont fault (fig. 5) is the major fault bounding the west flanks of the Beaver Dam and Virgin Mountains (Bohannon and others, 1993), and it forms the boundary between the Colorado Plateau and Basin and Range provinces $\left(A-A^{\prime}, B-B^{\prime}, C-C^{\prime}\right)$. In most areas, the fault juxtaposes an east-tilted section of Paleozoic and Mesozoic rocks overlain by thick TertiaryQuaternary basin-fill deposits in the hanging wall against Proterozoic crystalline rocks in the footwall ( $B-B^{\prime}$, and $\left.C-C^{\prime}\right)$. The fault is estimated to have about $12 \mathrm{~km}$ of normal separation (Bohannon and others, 1993) and was most active from 13 to $10 \mathrm{Ma}$ (Quigley and others, 2002). Quigley and others (2002) suggested that Cenozoic uplift in the Virgin-Beaver Dam Mountains along the Piedmont fault may have been controlled by older Proterozoic shear zones along a former accretionary crustal boundary. Carpenter and Carpenter (1994) reported the southern end of the fault, south of Mesquite (fig. 1), to have a left-lateral component as illustrated in sections $D-D^{\prime}, E-E^{\prime}$, and $J-J^{\prime}$.

Virgin Valley is segmented into two deep northeast-trending basins (fig. 4), the Mormon basin to the southwest and the Mesquite basin to the northeast (Bohannon and others, 1993; Langenheim and others, 2000, 2001a). The basins formed by subsidence caused by Miocene extension mainly along the Piedmont fault. Cenozoic basin-fill deposits in the Mesquite basin are estimated to have maximum thicknesses of about 8 to $10 \mathrm{~km}$, with the deepest part of the basin beneath the Littlefield, Ariz., area (Langenheim and others, 2000, 2001a) (fig. 2). Cross sections $B-B^{\prime}$ and $C-C^{\prime}$ extend across the Mesquite basin and show an east-dipping sequence of deformed Paleozoic and Mesozoic rocks overlain by moderately deformed Cenozoic basin-fill rocks. The subsurface stratigraphy and structure portrayed in the cross sections are derived mostly from seismic-reflection data from Bohannon and others (1993) and Carpenter and Carpenter (1994), and gravity data from Langenheim and others (2000, 2001a). Cross sections $D-D^{\prime}$ and $E-E^{\prime}$ extend across the Mormon basin where Cenozoic basin-fill deposits reach maximum thicknesses of 5 to $6 \mathrm{~km}$. The subsurface stratigraphy and structure portrayed in the cross sections in the Mormon basin is mostly from seismic-reflection data from Bohannon and others (1993), gravity data from Langenheim and others (2000, 2001a), and the Mobil Virgin River no. 1-A deep petroleum test well on Mormon Mesa. The Mobil well encountered the base of Cenozoic basin fill at about $2 \mathrm{~km}$, and the well bottomed out in Proterozoic crystalline rocks at about $5.9 \mathrm{~km}$ depth (Bohannon and others, 1993).

Muddy River Springs (fig. 2 and $D-D^{\prime}$ ) are structurally controlled by a broad northstriking fault zone that forms the east range front of the southern Meadow Valley Mountains and Arrow Canyon Range (Schmidt and Dixon, 1995; Schmidt and others, 1996; Page and others, 2005a). The fault zone is informally referred to here as the east Arrow Canyon Range fault zone 
(fig. 5). Faults in the fault zone are exposed in the Paleozoic carbonate rocks on the east flanks of the Meadow Valley Mountains (Schmidt, 1994) and Arrow Canyon Range (Page, 1992; Schmidt and others, 1996), and in the Cenozoic basin-fill deposits in lower Meadow Valley and California Wash. East-striking faults intersect the north-striking faults (Schmidt and others, 1996; Schmidt, 1994; Page and others, 2005) and potentially enhance permeability. Seismicreflection data (Scheirer and others, 2006) indicate an east-trending buried bedrock ridge separates lower Meadow Valley Wash basin from California Wash basin (fig. 4). The ridge is structurally controlled by east-striking faults (Scheirer and others, 2006), and it connects the Paleozoic carbonate rocks in the subsurface between the Arrow Canyon Range and Muddy Mountains. Near Ute (fig. 2), along the east flank of the Arrow Canyon Range, spring carbonate mounds represent past spring discharge from the fault zone (Schmidt and Dixon, 1995). Quaternary faults are exposed in this area, which may have increased permeability in the fault zone.

Cenozoic basin-fill deposits in California Wash basin are estimated to be 2 to $3 \mathrm{~km}$ deep based on gravity and seismic-reflection data (Langenheim and others, 2001b, 2002). The basin is bounded by the California Wash fault zone, a zone of west-dipping normal faults on the west flank of the Muddy Mountains $\left(E-E^{\prime}, F-F^{\prime}\right.$, and $\left.G-G^{\prime}\right)$. Bidgoli and others (2003) reported Quaternary faulting in the fault zone.

The Rogers Spring fault is located on the southeast side of the Muddy Mountains where it bounds a moderately deep basin in the Lake Mead Overton Arm area (fig. 5, $F-F^{\prime}$ ); Cenozoic basin-fill deposits are 2 to $3 \mathrm{~km}$ thick in the Overton Arm basin. The fault dips from $60^{\circ}$ to $70^{\circ}$ southeast and juxtaposes Paleozoic carbonate rocks of the Muddy Mountain thrust allochthon against deformed Tertiary basin-fill deposits that overlie autochthonous Mesozoic rocks $\left(F-F^{\prime}\right)$. Bohannon (1983) interpreted the fault as a normal fault, but he reported local evidence of strikeslip displacement suggesting multiple stages of movement. We agree with Bohannon's interpretation of strike-slip and normal movement on the fault, but a reverse component of displacement is also indicated because the Paleozoic allochthon of the Muddy Mountain thrust on the northwest side of the fault is presumably downdropped against autochthonous Mesozoic rocks on the southeast side $\left(F-F^{\prime}\right)$ based on exposure of the Jurassic Aztec Sandstone farther to the southwest along the fault. Rogers and Blue Point Springs are probably both structurally controlled by the Rogers Spring fault, and warm water discharging from the springs $\left(85^{\circ}-86^{\circ} \mathrm{F}\right)$ suggests a relatively deep source. The springs may exist partly due to juxtaposition of the Paleozoic-Mesozoic sequence in the fault footwall against Early Proterozoic crystalline rocks in the hanging wall, and the presence of thick basin-fill sediments containing impermeable evaporate deposits in the fault hanging wall (Laney and Bales, 1996).

\section{Summary}

The oldest rocks in the study area are Early Proterozoic crystalline rocks. These rocks form basement and are confining units in the regional groundwater flow systems. Late Proterozoic to Lower Cambrian rocks are predominantly clastic rocks and are also considered confining units in the region.

Above the Late Proterozoic to Lower Cambrian clastic rocks are Middle Cambrian to Lower Permian units that are predominantly carbonate rocks, and they form the main aquifer in the regional groundwater flow systems. The Paleozoic carbonate rocks thin from west to east in the study area, from as much as $7 \mathrm{~km}$ in the western part to less than $2 \mathrm{~km}$ in the eastern part. 
Much of the thinning resulted from erosion of individual units along major unconformities and stratigraphic thinning of individual units toward the craton.

Above the Paleozoic carbonate rocks are mainly clastic units of late Paleozoic to Mesozoic age that are generally considered confining units in the flow systems, but they may be permeable where fractured. Tertiary volcanic and plutonic rocks are exposed in the extreme northern and southern parts of the study area and may be aquifers where they are highly faulted, such as in the Delamar and Clover Mountains. Basin-fill deposits consist of middle to late Tertiary sediments of variable lithologies, and younger Quaternary surficial units consisting mainly of alluvium. Basin-fill sediments are both aquifers and aquitards in the region.

Movement of groundwater through the aquifers is through fractures and faults, and through solution channels formed in the carbonate rocks. The rocks in the area were complexly deformed by episodes of Mesozoic compression and Cenozoic extension. Cretaceous thrust faults and folds in the area formed during the Sevier orogeny. Duplex zones along some of the thrust faults resulted in structural thickening and define areas of maximum thickness of the Paleozoic carbonate rocks.

Cenozoic extensional tectonics affected the rocks in the region and included normal and strike-slip faulting, volcanism, and plutonism. Cenozoic faults are significant because they are the primary structures that control groundwater flow in the regional groundwater flow systems.

\section{Acknowledgments}

We thank William P. VanLiew, National Park Service, Water Resources Division, Fort Collins, Colo., for funding this work. Robert G. Bohannon and Robert B. Scott provided comprehensive technical reviews for the original report (U.S. Geological Open-File Report 2006-1040); Sue Beard and Kenzie Turner reviewed the revised report.

\section{References Cited}

Anderson, R.E., 1973, Large magnitude late Tertiary strike-slip faulting north of Lake Mead, Nevada: U.S. Geological Survey Professional Paper 794, 18 p.

Anderson, R.E., and Barnhard, T.P, 1993, Aspects of three-dimensional strain at the margin of the extensional orogen, Virgin River depression area, Nevada, Utah and Arizona: Geological Society of America Bulletin, v. 105, p. 1019-1052.

Anderson, R.E., Barnhard, T.P., and Snee, L.W., 1994, Roles of plutonism, midcrustal flow, tectonic rafting, and horizontal collapse in shaping the Miocene strain field of the Lake Mead area, Nevada and Arizona: Tectonics, v. 13, no. 6, p. 1381-1410.

Armstrong, R.L., 1968, Sevier orogenic belt in Nevada and Utah: Geological Society of America Bulletin, v. 79, p. 429-458.

Axen, G.J., Wernicke, B.P., Skelly, M.F., and Taylor, W.J., 1990, Mesozoic and Cenozoic tectonics of the Sevier thrust belt in the Virgin River Valley area, southern Nevada, in Wernicke, B.P., ed., Basin and Range extensional tectonics near the latitude of Las Vegas, Nevada: Geological Society of America Memoir 176, p. 123-154.

Belcher, W.R., Faunt, C.C., and D'Agnese, F.A., 2002, Three-dimensional hydrogeologic framework model for use with a steady-state numerical ground-water flow model of the Death Valley regional flow system, Nevada and California: U.S. Geological Survey Water-Resources Investigations Report 01-4254.

Bidgoli, T.S., Fossett, E., Knudsen, T.R., Kubart, Dano, Mcewan, D.J., and Taylor, W.J., 2003, Surface rupture, paleoseismology, and seismic hazard assessment of the Holocene California 
Wash fault, southern Nevada: implications for risk to greater Las Vegas area [abs.]: Geological Society of America Abstracts with Programs, v. 35. no. 6, p. 476.

Blakely, R.J., and Ponce, D.A., 2001, Map showing depth to pre-Cenozoic basement in the Death Valley ground-water model area, Nevada and California: U.S. Geological Survey Miscellaneous Field Studies Map MF-2381-E, scale 1:250:000.

Bohannon, R.G., 1983, Geologic map, tectonic map, and structure sections of the Muddy and northern Black Mountains, Clark County, Nevada: U.S. Geological Survey Miscellaneous Investigations Map I-1406, scale 1:62,500.

Bohannon, R.G., Grow, J.A., Miller, J.J., and Blank, R.H., Jr., 1993, Seismic stratigraphy and tectonic development of Virgin River depression and associated basins, southeastern Nevada and northwestern Arizona: Geological Society of America Bulletin, v. 105, p. 501-520.

Burbey, T.J., 1997, Hydrogeology and potential for ground-water development, carbonate-rock aquifers, southern Nevada and southeastern California: U.S. Geological Survey WaterResources Investigations Report 95-4168, 65 p.

Carpenter, J.A., and Carpenter, D.G., 1994, Structural and stratigraphic relations in a critical part of the Mormon Mountains, Nevada, in Dobbs, S.W., and Taylor, W.J., eds.: Nevada Petroleum Society 1994 Conference Volume II, (Book 1), p. 95-126.

D’Agnese, F.A., Faunt, C.C., Turner, K., and Hill, M.C., 1997, Hydrogeologic evaluation and numerical simulation of Death Valley regional ground-water flow system, Nevada and California: Water-Resources Investigations Report 96-4300, 124 p.

D’Agnese, F.A., O’Brien, G.M., Faunt, C.C., Belcher, W.R., and San Juan, Carma, 2002, A three-dimensional numerical model of predevelopment conditions in the Death Valley regional ground-water flow system, Nevada and California: U.S. Geological Survey Water-Resources Investigations Report 02-4102, 114 p.

Dettinger, M.D, Harrill, J.R., Schmidt, D.L., and Hess, J.W., 1995, Distribution of carbonaterock aquifers and the potential for their development, southern Nevada and adjacent parts of California, Arizona, and Utah: U.S. Geological Survey Water Resources Investigations Report 91-4146, 100p.

Dixon, G.L., and Katzer, T.L., 2002, Geology and hydrology of the lower Virgin River Valley in Nevada, Arizona, and Utah: Virgin Valley Water District, Mesquite, Nevada, Report no. VVWD-01, $126 \mathrm{p}$.

Duebendorfer, E.M., and Black, R.A., 1992, Kinematic role of transverse structures in continental extension: an example from the Las Vegas Valley shear zone, Nevada: Geology, v. 20, p. 1107-1110.

Duebendorfer, E.M., and Simpson, D.A., 1994, Kinematics and timing of Tertiary extension in the western Lake Mead region, Nevada: Geological Society of America Bulletin, v. 106, p. 1057-1073.

Eakin, T.E., 1964, Ground-water appraisal of Coyote Spring and Kane Springs valleys and Muddy River Springs area, Lincoln and Clark Counties, Nevada: Nevada Department of Conservation and Natural Resources, Ground-Water Resources Reconnaissance Series, Report $25,40 \mathrm{p}$.

Eakin, T.E., 1966, A regional interbasin groundwater system in the White River area, southeastern Nevada: Water Resources Research, v. 2, p. 251-271.

Faulds, J.E., Feuerbach, D.L., Miller, C.F., and Smith, E.I., 2001, Cenozoic evolution of the northern Colorado River extensional corridor, southern Nevada and northwest Arizona, in Erskine, M.C., Faulds, J.E., Bartley, J.M., and Rowley, P.D., eds., The geologic transition, 
High Plateaus to Great Basin-A symposium and field guide (The Mackin Volume): Utah Geological Association and Pacific Section of the American Association of Petroleum Geologists: Utah Geological Association Publication 30, p. 239-272.

Fleck, R.J., 1970, Tectonic style, magnitude, and age of deformation in the Sevier orogenic belt in southern Nevada and eastern California: Geological Society of America Bulletin, v. 81, p. $1705-1720$.

Fleck, R.J., and Carr, M.D., 1990, The age of the Keystone thrust: Laser-fusion ${ }^{40} \mathrm{Ar} /{ }^{39} \mathrm{Ar}$ dating of foreland basin deposits, southern Spring Mountains, Nevada: Tectonics, v. 9, p. 467-476.

Garside, L.J., Hess, R.H., Fleming, K.L., and Weimer, B.S., 1988, Oil and Gas development in Nevada: Nevada Bureau of Mines and Geology Bulletin 104, 136 p.

Guth, P.L., 1980, Geology of the Sheep Range, Clark County, Nevada: Boston, Massachusetts, Institute of Technology, Ph.D. dissertation, $189 \mathrm{p}$.

Guth, P.L., 1981, Tertiary extension north of the Las Vegas Valley shear zone, Sheep and Desert Ranges, Clark County, Nevada: Geological Society of America Bulletin, v. 92, p. 763-771.

Guth, P.L., 1990, Superposed Mesozoic and Cenozoic deformation Indian Springs quadrangle, southern Nevada, in Wernicke, B.P., ed., Basin and Range extensional tectonics near the latitude of Las Vegas, Nevada: Geological Society of America Memoir 176, p. 123-154.

Harding, A.E., Scott, R.B., Mehnert, H.H., and Snee, L.W., 1995, Evidence of the Kane Springs Wash caldera in the Meadow Valley Mountains, southeastern Nevada, in Scott, R.B., and Swadley, WC, eds., Geologic Studies in the Basin and Range-Colorado Plateau Transition in Southeastern Nevada, Southwestern Utah, and Northwestern Arizona: U. S. Geological Survey Bulletin 2056, p. 135-167.

Harrill, J.R., and Prudic, D.E., 1998, Aquifer systems in the Great Basin region of Nevada, Utah and adjacent states - Summary report: U.S. Geological Survey Professional Paper 1409A, $61 \mathrm{p}$.

Heilweil, V.M., Watt, D.E., Solomon, D.K., and Goddard, K.E., 2002, The Navajo aquifer system of southwestern Utah, in Lund, W.R., ed., Field Guide to Geologic Excursions in Southwestern Utah and Adjacent areas of Arizona and Nevada, Geological Society of America Rocky Mountain Section Meeting, Cedar City, Utah, May 7th-9th, 2002: U.S. Geological Survey Open-File Report 02-172, p. 105-130.

Hintze, L.F., and Axen, G.J., 2001, Geologic map of the Lime Mountain Quadrangle, Lincoln County, Nevada: Nevada Bureau of Mines and Geology Map 129, scale 1:24,000.

Jachens, R.C., Dixon, G.L., Langenheim, V.E., and Morin, R., 1998, Interpretation of an aeromagnetic survey over part of Virgin Valley, Tule Desert, and the valley surrounding Meadow Valley Wash, southeastern Nevada: U.S. Geological Survey Open-File Report 98$804,16 \mathrm{p}$.

Johnson, M., Dixon, G.L., Rowley, P.D., Katzer, T.L., and Winters, M., 2002, Hydrology and ground-water conditions of the Tertiary Muddy Creek Formation in the lower Virgin River basin of southeastern Nevada and adjacent Arizona and Utah, in Lund, W.R., ed., Field guide to geologic excursions in southwestern Utah and adjacent areas of Arizona and Nevada, Field trip guide, Geological Society of America, Rocky Mountain section meeting, Cedar City, Utah: U.S. Geological Survey Open-File Report 02-172, p. 284-315.

Kirk, S.T., 1987, Analysis of the White River groundwater flow system using a deuteriumcalibrated discrete-state compartment model: Reno, University of Nevada, M.S. thesis, 81 p. 
Laczniak, R.J., Cole, J.C., Sawyer, D.A., and Trudeau, D.A., 1996, Summary of hydrogeologic controls on ground-water flow at the Nevada Test Site, Nye County, Nevada: U.S. Geological Survey Water-Resources Investigations Report 96-4109, 60 p.

Laney, R.L., and Bales, J.T., 1996, Geohydrologic reconnaissance of Lake Mead National Recreation area-Las Vegas Wash to Virgin River, Nevada: U.S. Geological Survey Water Resources Investigations Report 96-4033, 29 p.

Langenheim, V.E., Glen, J.M., Jachens, R.C., Dixon, G.L., Katzer, T.C., and Morin, R.L., 2000, Geophysical constraints on the Virgin River depression, Nevada, Utah, and Arizona: U.S. Geological Survey Open-File Report 00-407, 26 p.

Langenheim, V.E., Bohannon, R.G., Glen, J.M., Jachens, R.C., Grow, J.A., Miller, J.J., Dixon, G.L., and Katzer, T.L., 2001a, Basin configuration of the Virgin River depression, Nevada, Utah, and Arizona-A geophysical view of deformation along the Colorado Plateau-Basin and Range transition, in Erskine, M.C., Faulds, J.E., Bartley, J.M., and Rowley, P.D., eds., The geologic transition, High Plateaus to Great Basin-A symposium and field guide (The Mackin Volume): Utah Geological Association and Pacific Section of the American Association of Petroleum Geologists: Utah Geological Association Publication 30, p. 205-226.

Langenheim, V.E., Miller, J.J., Page, W.R., and Grow, J.A., 2001b, Thickness and geometry of Cenozoic deposits in California Wash area, Nevada, based on gravity and seismic reflection data: U.S. Geological Survey Open-File Report 01-393, 24 p.

Langenheim, V.E., Page, W.R., Miller, J.J., and Grow, J.A., 2002, Geophysical and geological constraints on the hydrogeologic framework of the California Wash region, southern Nevada: Geological Society of America Abstracts with Programs, v. 34, no. 4, p. A-16.

Nelson, M.R., and Jones, C.H., 1987, Paleomagnetism and crustal rotations along a shear zone, Las Vegas Range, southern Nevada: Tectonics, v. 6, no. 1, p. 13-33.

Page, W.R., 1990, Effects of Tertiary extension on the Mesozoic Delamar thrust plate, southern Nevada [abs.]: Geological Society of America Abstracts with Programs, v. 22, no. 3, p. 74.

Page, W.R., 1992, Preliminary geologic map of the Arrow Canyon Quadrangle, Clark County, Nevada: U.S. Geological Survey Open-File Report 92-681, scale 1:24,000.

Page, W.R., 1998, Geologic map of the Arrow Canyon NW quadrangle, Clark County, Nevada: U.S. Geological Survey Geologic Quadrangle Map GQ-1776; scale 1:24,000.

Page, W.R., and Dixon, G.L., 1992, Northern terminus of the Mesozoic Dry Lake thrust fault, Arrow Canyon Range, southeastern Nevada: Geological Society of America Abstracts with Programs, v. 24, no. 6, p. 56.

Page, W.R., Dixon, G.L., Rowley, P.D, and Brickey, D.W., 2005a, Geologic map of parts of the Colorado, White River, and Death Valley groundwater flow systems, Nevada, Utah, and Arizona: Nevada Bureau of Mines and Geology Map 150, scale 1:250,000.

Page, W.R., Lundstrom, S.C., Harris, A.G., Langenheim, V.E., Workman, J.B., Mahan, S.A., Paces, J.B., Rowley, P.D., Dixon, G.L., Burchfiel, B.C., Bell, J.W., and Smith, E.I., 2005b, Geologic and geophysical maps of the Las Vegas 30' x 60' Quadrangle, Clark and Nye Counties, Nevada, and Inyo County, California: U.S. Geological Survey Scientific Investigations Map 2814, scale 1:100,000.

Page, W.R., and Pampeyan, E.H., 1996, Preliminary geologic map of the Paleozoic rocks in the Wildcat Wash SE and Wildcat Wash SW Quadrangles, Lincoln and Clark Counties, Nevada: U.S. Geological Survey Open-File Report 96-26, 18 p., scale 1:24,000. 
Page, W.R., Swadley, W C, and Scott, R.B., 1990, Preliminary geologic map of the Delamar 3 SW quadrangle, Lincoln County, Nevada: U.S. Geological Survey Open-File Report 90-336, scale 1:24,000.

Pampeyan, E.H., 1993, Geologic map of the Meadow Valley Mountains, Lincoln and Clark Counties, Nevada: U.S. Geological Survey Miscellaneous Investigations Series Map I-2173, scale 1:50,000.

Phelps, G.A., Jewel, E.B., Langenheim, V.E., and Jachens, R.C., 2000, Principal facts for gravity stations in the vicinity of Coyote Spring Valley, Nevada, with initial gravity modeling results: U.S. Geological Survey Open-File Report 00-420, 18 p.

Plume, R.W., and Carlton, S.M., 1988, Hydrogeology of the Great Basin region of Nevada, Utah, and adjacent states: U.S. Geological Survey Hydrologic Investigations Atlas HA-694A, scale 1:1,000,000.

Prudic, D.E., Harrill, J.R., and Burbey, T.J., 1995, Conceptual evaluation of regional groundwater flow in the carbonate-rock province of the Great Basin, Nevada, Utah, and adjacent states: U.S. Geological Survey Professional Paper 1409-D, 102 p.

Quigley, M.C., Karlstrom, K., Beard, S., and Bohannon, R.G., 2002, Influence of Proterozoic and Laramide structures on the Miocene extensional strain field, north Virgin Mountains, Nevada/Arizona, in Lund, W.R., ed., Field Guide to Geologic Excursions in Southwestern Utah and Adjacent areas of Arizona and Nevada, Geological Society of America Rocky Mountain Section Meeting, Cedar City, Utah, May 7th-9th, 2002; U.S. Geological Survey Open-File Report 02-172, p. 86-104.

Rogers, A.M., Harmsen, S.C., and Meremonte, M.E., 1987, Evaluation of the seismicity of the southern Great Basin and its relationship to the tectonic framework of the region: U.S. Geological Survey Open-File Report 87-408, 196 p.

Rowley, P.D., 1998, Cenozoic transverse zones and igneous belts in the Great Basin, western United States--their tectonic and economic implications, in Faulds, J.E., and Stewart, J.H., eds., Accommodation zones and transfer zones--the regional segmentation of the Basin and Range province: Geological Society of America Special Paper 323, p. 195-228.

Rowley, P.D., Nealey, L.D., Unruh, D.M., Snee, L.W., Mehnert, H.H., Anderson, R.E., and Gromme, C.S., 1995, Stratigraphy of Miocene ash-flow tuffs in and near the Caliente Caldera complex, southeastern Nevada and southwestern Utah, in Scott, R.B., and Swadley, WC, eds., Geologic studies in the Basin and Range-Colorado Plateau transition in southeastern Nevada, southwestern Utah, and northwestern Arizona, 1992: U.S Geological Survey Bulletin 2056, p. 43-88.

Scheirer, D.S., Page, W.R., and Miller, J.J., 2006, Geophysical studies based on seismic and gravity data of Tule Desert, Meadow Valley Wash, and California Wash basins, southern Nevada: U.S. Geological Survey Open-File Report 2006-1396, 42 p.

Schmidt, D.L., 1994, Preliminary geologic map of the Farrier Quadrangle, Lincoln and Clark Counties, Nevada: U.S. Geological Survey Open File Report 94-625, scale 1:24,000.

Schmidt, D.L., and Dixon, G.L., 1995, Geology and aquifer system of the Coyote Spring Valley area, southeastern Nevada: U.S. Geological Survey Open-File Report 95-579, 47 p.

Schmidt, D.L., Page, W.R., and Workman, J.B., 1996, Preliminary geologic map of the Moapa West Quadrangle, Clark County, Nevada: U.S. Geological Survey Open-File Report 96-521, scale 1:24,000. 
Scott, R. B., Unruh, D.M., Snee, L.W., Harding, A.E., Nealey, L.D., Blank, H.R., Jr., Budahn, J.E., and Mehnert, H.H., 1995, Relation of peralkaline magmatism to heterogeneous extension during middle Miocene: Journal of Geophysical Research, v. 100, p. 10381-10401.

Sonder, L.J., Jones, C.H., Salyards, S.L., and Murphy, K.M., 1994, Vertical axis rotations in the Las Vegas Valley shear zone, southern Nevada: paleomagnetic constraints on kinematics and dynamics of block rotations: Tectonics, v. 13, p. 769-788.

Stewart, J.H., 1972, Initial deposits in the Cordilleran geosyncline: evidence of a late Precambrian (<850 m.y.) continental separation: Geological Society of America Bulletin, v. 83 , p. $1345-1360$.

Stewart, J.H., 1976, Late Precambrian evolution of North America: plate tectonics implication: Geology, v. 4, p. 11-15.

Stewart, J.H., and Poole, F.G., 1972, Lower Paleozoic and uppermost Precambrian Cordilleran Miogeocline, Great Basin, western United States, in Dickinson, W.R., ed., Tectonics and Sedimentation, Society of Economic Paleontologists and Mineralogists Special Publication 22, p. $28-57$.

Swadley, W.C., Page, W.R., Scott, R.B., and Pampeyan, E.H., 1994, Geologic map of the Delamar 3 SE Quadrangle, Lincoln County, Nevada: U.S. Geological Survey Geologic Quadrangle Map-GQ-1754, scale 1:24,000.

Swadley, W.C., 1995, Maps showing modern fissures and Quaternary faults in the Dry Lake Valley area, Lincoln County, Nevada: U.S. Geological Survey Miscellaneous Field Investigations Series, Map I-2501, scale 1:50,000.

Sweetkind, D.S., Dickerson, R.P, Blakely, R.J., and Denning, P.D., 2001, Interpretive cross sections for the Death Valley regional flow system and surrounding areas, Nevada and California: U.S. Geological Survey Miscellaneous Field Studies Map MF-2370, 32 p., one map sheet.

Thomas, J.M., Mason, J.L., and Crabtree, J.D., 1986, Ground-water levels in the Great Basin region of Nevada, Utah, and adjacent states: U.S. Geological Survey Hydrologic Investigations Atlas HA-694-B, scale 1:1,000,000.

Thomas, J.M., and Welch, A.H., 1984, Isotope hydrology and aqueous geochemistry of the White River Groundwater basin, a regional carbonate aquifer in eastern Nevada: Geological Society of America Abstracts with Programs, v. 16, no. 6, p. 689.

Tschanz, C.M., and Pampeyan, E.H., 1970, Geology and Mineral deposits of Lincoln County, Nevada: Nevada Bureau of Mines and Geology Bulletin 73, 188 p.

Wernicke, Brian, Guth, P.L., and Axen, G.J., 1988, Tertiary extensional tectonics in the Sevier thrust belt of southern Nevada, in Weide, D.L., and Faber, M.L., eds., This Extended Land; Geological journeys in the southern Basin and Range; Geological Society of America Cordilleran Section Field Trip Guidebook: University of Nevada at Las Vegas Geoscience Department Special Publication no. 2, p. 473-499.

Wernicke, Brian, Spencer, J.E., Burchfiel, B.C., and Guth, P.L., 1982, Magnitude of crustal extension in the southern Great Basin: Geology, v. 10, p. 499-502.

Wernicke, Brian, Walker, D.J., and Beaufait, M.S., 1985, Structural discordance between Neogene detachments and frontal Sevier thrusts, Central Mormon Mountains, Southern Nevada: Tectonics, v. 4, no. 2, p. 213-246.

Wilson, J.W., 2001, Potentiometric surface, carbonate-rock province, southern Nevada and southeastern California, 1998-2000: U.S. Geological Survey Open-File Report 01-335, 15 p. 
Winograd, I.J., and Thordarson, W., 1975, Hydrologic and hydrochemical framework, southcentral Great Basin, Nevada-California, with special reference to the Nevada Test Site: U.S. Geological Survey Professional Paper 712C, p. C1-C126.

Workman, J.B., Menges, C.M., Page, W.R., Ekren, E.B., Rowley, P.D., and Dixon, G.L., 2002a, Tectonic map of the Death Valley ground-water model area, Nevada and California: U.S. Geological Survey Miscellaneous Field Studies Map MF-2381-B, 58 p.

Workman, J.B., Menges, C.M., Page, W.R., Taylor, E.M., Ekren, E.B., Rowley, P.D., Dixon, G.L., Thompson, R.A., and Wright, L.A., 2002b, Geologic map of the Death Valley ground water model area, Nevada and California: U.S. Geological Survey Miscellaneous Field Studies MF-2381-A, scale 1:250,000. 